\title{
DIRECTION OF CHANGES IN DEMAND \\ FOR RAIL FREIGHT TRANSPORT \\ WITHIN THE EUROPEAN UNION COUNTRIES \\ IN THE YEARS 1990-2013
}

\section{JULIUSZ ENGELHARDT}

The University of Szczecin, POLAND

e-mail: juliusz.engalhardt@wzieu.pl

\section{RECEIVED \\ ACCEPTED \\ JEL \\ CLASSIFICATION}

KEYWORDS

ABSTRACT
12 May 2018

1 September 2018

L98, N74, 018, R42, R48

European Union rail freight market, rail freight transport, structural trends in rail transport

The article discusses the main trends of changes in the volume of rail freight transport in the European Union between 1990-2013 in the context of the entire EU freight market. Furthermore, rail freight transport was analysed breaking it down to the "old Fifteen" countries and the new member states of the European Union EU 11. In the EU 15 group, the demand for rail freight transport differed from the corresponding demand in the EU 11 countries. The aim of this article is a preliminary verification of the hypothesis, according to which reforms of the railway sector undertaken by means of its demonopolization and general liberalization were to lead to a significant increase in the share of rail transport in the EU freight market. In the final part, the main factors shaping the demand for rail freight were indicated.

\section{Introduction}

Following the restriction included in the title, the article discuses only the main factors, which in the author's opinion, affect changes in the level and structure of rail freight transport in the European Union countries, identified on the basis of available transport statistics. The implemented policy of changes in the EU railway sector constitutes a general framework for the analyses presented in the article. On the basis of the European Union's policy papers, 
it can be pointed out that the main objectives of the railway sector reforms undertaken at the beginning of the 1990s were, inter alia:

- demonopolization of the railway sector, through the abolition of state railway monopolies and admission of many independent domestic and foreign transport operators to the railway network,

- separation of railway infrastructure management activities from railway operation- transport activities,

- elimination or alleviation of existing barriers to enter the rail freight transport market for new enterprises, in particular private ones - development of intra-industry competition in railway transport by "soft" licensing of entities entering the sector, as well as elimination of barriers in the scope of international rail transport and further development of this segment of transport.

The implementation of these objectives was to lead to an overall improvement in the rail transport efficiency, a relative reduction in the cost of its operation, improvement of the quality and competitiveness of transport services, and, eventually, an increase in the relative share of railways in the transport markets. It can be assumed, in a conventional manner, that the re-evaluation of the concept, as well as the effect of broad political discussion on the further functioning of the railway sector in the European Union, resulted in the adoption of Directive 91/440 on the development of the Community's railways ${ }^{1}$ by the Council of the European Union on 29 July 1991. The date of adoption of this directive is an important turning point in the history of the European rail industry. Since that moment, demonopolization and liberalization of railway transport, aimed at a comprehensive introduction of market mechanisms in rail transport and enabling new railway undertakings to enter the transport market, has become the fundamental standard of the European Union rail transport policy in the scope of shaping a new market order. The first "liberalization" railway directive from 1991 was followed by further regulations. Due to the fact that they were grouped in the past (several legal acts adopted in the same period of time), the name "railway packages" was adopted for a part of these regulations. ${ }^{2}$ Since 2013 , following the adoption of the next directive, there has been functioning the Single European Railway Area. ${ }^{3}$

The aim of this article is a preliminary verification of the hypothesis, based on the available transport statistics, according to which reforms of the railway sector undertaken by means of its demonopolization and general liberalization were to lead to a significant increase in the share of rail transport in the EU freight market.

\section{The European Union rail freight market in the years 1995-2013}

An analysis of transport statistics allows identifying some market trends occurring especially during longer periods of time. Tables 1 and 2 present numerical data of the freight transport market in the European Union ${ }^{4}$ in the years 1995-2013 expressed in the indicators of transport services in tonne-kilometres. Based on the data from Table 1, it can be observed that the entire freight transport market in the European Union increased in 1995-2013 by 635 billion tkm (or 22.3\%). However, considering the particular branches of transport, this increase has not been

\footnotetext{
1 The Official Journal of the European Communities 1991, L 237/25.
}

2 The first package was adopted in 2001, the second one in 2004, whereas the third was adopted in 2007.

${ }^{3}$ Directive 2012/34/EU of the European Parliament and of the Council of 21 November 2012 establishing a single European railway area - the Official Journal of the European Union 2012, L 343/32

${ }^{4}$ Statistics on freight and passenger transport published in the European Union cover 28 member countries. In the case of railway transport, however, transport statistics concern 26 countries, as two Member States, i.e, Cyprus and Malta, do not have a railway network. 
evenly distributed. Road transport increased during this period by 430 billion tkm $(33.4 \%)$, which is $11.1 \%$ more than the increase in the entire market, while rail freight transport increased by only 19 billion tkm, i.e., by $4.7 \%$, thus being much below the growth rate of the entire market. In the period of 1995-2013, the average annual growth rate of road transport amounted to $1.6 \%$, while rail transport increased at the rate of $0.3 \%$ per year. It is also worth noting that during the period in question, inland waterway transport increased by 31 billion tkm (25.1\%).

Table 1. Freight transport in the European Union countries in the years 1995-2013, in billion tonne-kilometres

\begin{tabular}{|c|c|c|c|c|c|c|c|}
\hline Year & Road transport & Rail transport & Inland navigation & $\begin{array}{l}\text { Pipeline } \\
\text { transport }\end{array}$ & $\begin{array}{c}\text { Maritime } \\
\text { navigation }\end{array}$ & Air transport ${ }^{*}$ & Total \\
\hline 1995 & 1,289 & 388 & 122 & 115 & 930 & 2 & 2,846 \\
\hline 1996 & 1,303 & 394 & 120 & 119 & 942 & 2 & 2,879 \\
\hline 1997 & 1,352 & 411 & 128 & 119 & 969 & 2 & 2,980 \\
\hline 1998 & 1,414 & 394 & 131 & 126 & 1,000 & 2 & 3,068 \\
\hline 1999 & 1,461 & 385 & 129 & 125 & 1,029 & 2 & 3,131 \\
\hline 2000 & 1,509 & 405 & 134 & 127 & 1,067 & 2 & 3,245 \\
\hline 2001 & 1,553 & 388 & 133 & 134 & 1,083 & 2 & 3,292 \\
\hline 2002 & 1,603 & 386 & 133 & 130 & 1,100 & 2 & 3,353 \\
\hline 2003 & 1,608 & 394 & 124 & 132 & 1,119 & 2 & 3,378 \\
\hline 2004 & 1,751 & 419 & 137 & 133 & 1,159 & 2 & 3,601 \\
\hline 2005 & 1,795 & 416 & 139 & 138 & 1,198 & 2 & 3,687 \\
\hline 2006 & 1,858 & 438 & 139 & 137 & 1,224 & 2 & 3,798 \\
\hline 2007 & 1,925 & 452 & 145 & 128 & 1,190 & 2 & 3,843 \\
\hline 2008 & 1,891 & 443 & 146 & 125 & 1,164 & 2 & 3,771 \\
\hline 2009 & 1,700 & 364 & 131 & 122 & 1,062 & 2 & 3,380 \\
\hline 2010 & 1,755 & 394 & 156 & 121 & 1,118 & 2 & 3,546 \\
\hline 2011 & 1,744 & 422 & 142 & 118 & 1,133 & 2 & 3,562 \\
\hline 2012 & 1,693 & 407 & 150 & 115 & 1,113 & 2 & 3,480 \\
\hline 2013 & 1,719 & 407 & 153 & 112 & 1,089 & 2 & 3,481 \\
\hline
\end{tabular}

"Maritime navigation and air transport only in the scope of internal transport.

Source: www.ec.europa.eu/transport/facts-fundings/statistic/pocketbook-2015_en.

Table 2. The structure of freight transport in the European Union countries in the years 1995- 2013, in \% tonne-kilometres

\begin{tabular}{ccccccc}
\hline Years & Road transport & Rail transport & Inland navigation & Pipeline transport & $\begin{array}{c}\text { Maritime } \\
\text { navigation }\end{array}$ & Air transport \\
\hline 1 & 2 & 3 & 4 & 5 & 6 & 7 \\
\hline 1995 & 45.3 & 13.6 & 4.3 & 4.0 & 32.7 & 0.1 \\
1996 & 45.2 & 13.7 & 4.2 & 4.1 & 32.7 & 0.1 \\
1997 & 45.4 & 13.8 & 4.3 & 4.0 & 32.5 & 0.1 \\
1998 & 46.1 & 12.9 & 4.3 & 4.1 & 32.6 & 0.1 \\
1999 & 46.7 & 12.3 & 4.1 & 4.0 & 32.9 & 0.1 \\
2000 & 46.5 & 12.5 & 4.1 & 3.9 & 32.9 & 0.1 \\
2001 & 47.2 & 11.8 & 4.0 & 4.1 & 32.9 & 0.1 \\
2002 & 47.8 & 11.5 & 4.0 & 3.9 & 32.8 & 0.1 \\
2003 & 47.6 & 11.7 & 3.7 & 3.9 & 33.1 & 0.1 \\
\hline
\end{tabular}




\begin{tabular}{|c|c|c|c|c|c|c|}
\hline 1 & 2 & 3 & 4 & 5 & 6 & 7 \\
\hline 2004 & 48.6 & 11.6 & 3.8 & 3.7 & 32.2 & 0.1 \\
\hline 2005 & 48.7 & 11.3 & 3.8 & 3.7 & 32.5 & 0.1 \\
\hline 2006 & 48.9 & 11.5 & 3.6 & 3.6 & 32.2 & 0.1 \\
\hline 2007 & 50.1 & 11.8 & 3.8 & 3.3 & 31.0 & 0.1 \\
\hline 2008 & 50.1 & 11.7 & 3.9 & 3.3 & 30.9 & 0.1 \\
\hline 2009 & 50.3 & 10.8 & 3.9 & 3.6 & 31.4 & 0.1 \\
\hline 2010 & 49.5 & 11.1 & 4.4 & 3.4 & 31.5 & 0.1 \\
\hline 2011 & 49.0 & 11.9 & 4.0 & 3.3 & 31.8 & 0.1 \\
\hline 2012 & 48.6 & 11.7 & 4.3 & 3.3 & 32.0 & 0.1 \\
\hline 2013 & 49.4 & 11.7 & 4.4 & 3.2 & 31.3 & 0.1 \\
\hline
\end{tabular}

Source: calculated on the basis of Table 1.

As a result of the above trends, the indicators of relative market share presented in Table 2 have increased especially in the scope of road transport from $45.3 \%$ in 1995 to $49.4 \%$ in 2013 , and decreased in the scope of the rail transport from $13.6 \%$ in 1995 to $11.7 \%$ in 2013 . The table also shows that inland navigation in 2013 , due to the increase number of transport services, maintained its market share from 1995, while maritime navigation, despite a significant increase in transport services, decreased its relative market share in 2013 by $1.5 \%$, if compared to 1995.

\section{Rail freight transport in the European Union countries in the years 1995-2013}

The previously indicated decline in the share of rail freight in the entire transport market did not equally concern all European Union countries, as shown in Table 3 and Figure 1. Table 3 lists the volumes of rail freight transport in billion tonne-kilometres by country. The data indicates that in 1990-1993, the rail freight market was decreasing in almost all countries of today's European Union. The only exception were the small rail freight transport markets in Portugal and Luxembourg. In many countries, the downward trend in rail freight transport was stopped in 1994-1995. Since then, there has been observed a division of the EU's entire rail freight market into three segments, i.e. growing, stable and decreasing. In some economies of Western European countries, such as Germany, the United Kingdom, Austria, the Netherlands and Sweden, the growing trend of the rail freight market was maintained in the years 1995-2013. It is worth noting a similar trend in this period in smaller countries of Central and Eastern Europe, such as Lithuania and Latvia, as well as Hungary or Slovenia. On the other hand, the market of the third Baltic country, i.e., Estonia, was characterized by a large amplitude of fluctuations in 1995-2013, from transport at the level of 3.8 billion tkm in 1995 to 10.6 billion tkm in 2005, and then to 4.7 billion tkm in 2013 . The fluctuations were highly affected by the changes in railway transit transport to and from Russia. The markets stable in terms of rail freight transport in the years 1995-2013 include Belgium, Denmark, Croatia, Portugal and Finland. It should be noted, however, that the total share of these countries in the entire rail freight market in the European Union was not high. The previously not mentioned countries of the European Union were characterized by the decrease in the rail freight market between 1995-2013. This group mainly includes countries of Central and Eastern Europe, such as Poland, the Czech Republic, Bulgaria, Romania and Slovakia, as well as Italy and France. In the case of Italy, changing trends concern the rail freight market in 1995-2013. The market in this country grew from 21.7 billion tkm in 1995 to 22.8 billion tkm in 2000 . After that period, it decreased to 20.3 billion tkm in 2003, to rise again to 
Table 3. Rail freight transport in the European Union in the years 1990-2013 (billion tkm)

\begin{tabular}{|c|c|c|c|c|c|c|c|c|c|c|c|c|}
\hline Country & 1990 & 1991 & 1992 & 1993 & 1994 & 1995 & 1996 & 1997 & 1998 & 1999 & 2000 & 2001 \\
\hline $\mathrm{BE}$ & 8.4 & 8.2 & 8.4 & 7.6 & 8.1 & 7.3 & 7.2 & 7.5 & 7.6 & 7.4 & 7.7 & 7.1 \\
\hline$B G$ & 14.1 & 8.7 & 7.8 & 7.7 & 7.8 & 8.6 & 7.5 & 7.4 & 6.2 & 5.2 & 5.5 & 4.9 \\
\hline$C Z$ & & & & 25.2 & 22.8 & 22.6 & 22.3 & 21.0 & 18.7 & 16.7 & 17.5 & 16.9 \\
\hline DK & 1.7 & 1.9 & 1.9 & 1.8 & 2.0 & 2.0 & 1.8 & 2.0 & 2.1 & 1.9 & 2.0 & 2.1 \\
\hline DE & 101.7 & 82.2 & 72.8 & 65.6 & 70.7 & 70.5 & 70.0 & 73.9 & 74.2 & 76.8 & 82.7 & 81.0 \\
\hline $\mathrm{EE}$ & 7.0 & 6.5 & 3.4 & 4.2 & 3.6 & 3.8 & 4.2 & 5.1 & 6.1 & 7.3 & 8.1 & 8.6 \\
\hline IE & 0.6 & 0.6 & 0.6 & 0.6 & 0.6 & 0.6 & 0.6 & 0.5 & 0.5 & 0.5 & 0.5 & 0.5 \\
\hline EL & 0.6 & 0.6 & 0.5 & 0.5 & 0.3 & 0.3 & 0.3 & 0.3 & 0.3 & 0.3 & 0.4 & 0.4 \\
\hline ES & 11.2 & 10.5 & 9.2 & 7.8 & 9.1 & 11.0 & 11.1 & 12.5 & 11.3 & 11.5 & 11.6 & 11.7 \\
\hline FR & 52.2 & 52.4 & 51.2 & 45.6 & 48.9 & 48.3 & 50.1 & 54.2 & 54.1 & 54.5 & 57.7 & 51.7 \\
\hline $\mathrm{HR}$ & & & & & & 2.0 & 1.7 & 1.7 & 1.8 & 1.7 & 1.8 & 2.1 \\
\hline IT & 19.4 & 20.0 & 19.3 & 18.1 & 20.4 & 21.7 & 21.0 & 22.9 & 22.5 & 21.5 & 22.8 & 21.8 \\
\hline LV & 18.5 & 16.7 & 10.1 & 9.9 & 9.5 & 9.8 & 12.4 & 14.0 & 13.0 & 12.2 & 13.3 & 14.2 \\
\hline LT & 19.3 & 17.7 & 11.3 & 9.9 & 8.0 & 7.2 & 8.1 & 8.6 & 8.3 & 7.8 & 8.9 & 7.7 \\
\hline LU & 0.6 & 0.6 & 0.6 & 0.6 & 0.6 & 0.5 & 0.5 & 0.6 & 0.6 & 0.6 & 0.6 & 0.6 \\
\hline HU & 16.8 & 11.9 & 10.0 & 7.7 & 7.7 & 8.4 & 7.6 & 8.1 & 8.2 & 8.5 & 8.8 & 7.7 \\
\hline NL & 3.1 & 3.0 & 2.8 & 2.7 & 2.8 & 3.1 & 3.1 & 3.4 & 3.8 & 4.0 & 4.5 & 4.3 \\
\hline AT & 12.2 & 12.3 & 11.6 & 11.2 & 12.4 & 13.2 & 13.3 & 14.2 & 14.7 & 15.0 & 16.6 & 16.9 \\
\hline PL & 81.6 & 65.2 & 57.8 & 63.2 & 64.7 & 68.2 & 67.4 & 67.7 & 60.9 & 55.1 & 54.0 & 47.7 \\
\hline PT & 1.5 & 1.7 & 1.8 & 1.7 & 1.6 & 2.0 & 1.9 & 2.2 & 2.0 & 2.2 & 2.2 & 2.1 \\
\hline RO & 48.9 & 32.6 & 24.4 & 22.0 & 21.7 & 17.9 & 24.3 & 22.1 & 16.6 & 14.7 & 16.4 & 16.1 \\
\hline SI & 4.2 & 3.2 & 2.6 & 2.3 & 2.5 & 3.1 & 2.6 & 2.9 & 2.9 & 2.8 & 2.9 & 2.8 \\
\hline SK & & & & 14.2 & 12.2 & 13.8 & 12.0 & 12.4 & 11.8 & 9.9 & 11.2 & 10.9 \\
\hline $\mathrm{FI}$ & 8.4 & 7.6 & 7.8 & 9.3 & 9.9 & 9.6 & 8.8 & 9.9 & 9.9 & 9.8 & 10.1 & 9.9 \\
\hline SE & 19.1 & 18.8 & 19.2 & 18.6 & 19.1 & 19.4 & 18.8 & 19.2 & 19.2 & 19.1 & 19.5 & 19.0 \\
\hline UK & 16.0 & 15.3 & 15.5 & 13.8 & 13.0 & 13.3 & 15.1 & 16.9 & 17.3 & 18.2 & 18.1 & 19.4 \\
\hline
\end{tabular}

Table 3, cont'd

\begin{tabular}{|c|c|c|c|c|c|c|c|c|c|c|c|c|}
\hline Country & 2002 & 2003 & 2004 & 2005 & 2006 & 2007 & 2008 & 2009 & 2010 & 2011 & 2012 & 2013 \\
\hline 1 & 2 & 3 & 4 & 5 & 6 & 7 & 8 & 9 & 10 & 11 & 12 & 13 \\
\hline $\mathrm{BE}$ & 7.3 & 7.3 & 7.7 & 8.1 & 8.6 & 9.3 & 8.9 & 6.4 & 7.5 & 7.6 & 7.3 & 7.3 \\
\hline$B G$ & 4.6 & 5.3 & 5.2 & 5.2 & 5.4 & 5.2 & 4.7 & 3.1 & 3.1 & 3.3 & 2.9 & 3.2 \\
\hline$C Z$ & 15.8 & 15.9 & 15,1 & 14.9 & 15.8 & 16.3 & 15.4 & 12.8 & 13.8 & 14.3 & 14.3 & 14.0 \\
\hline DK & 1.9 & 2.0 & 2.3 & 2.0 & 1.9 & 1.8 & 1.9 & 1.7 & 2.2 & 2.6 & 2.3 & 2.4 \\
\hline $\mathrm{DE}$ & 81.1 & 85.1 & 91.9 & 95.4 & 107.0 & 114.6 & 115.7 & 95.8 & 107.3 & 113.3 & 110.1 & 112.6 \\
\hline EE & 9.7 & 9.7 & 10.5 & 10.6 & 10.4 & 8.4 & 5.9 & 5.9 & 6.6 & 6.3 & 5.1 & 4.7 \\
\hline IE & 0.4 & 0.4 & 0.4 & 0.3 & 0.2 & 0.1 & 0.1 & 0.1 & 0.1 & 0.1 & 0.1 & 0.1 \\
\hline EL & 0.3 & 0.5 & 0.6 & 0.6 & 0.7 & 0.8 & 0.8 & 0.6 & 0.6 & 0.4 & 0.3 & 0.2 \\
\hline ES & 11.6 & 11.7 & 12.4 & 11.6 & 11.5 & 11.2 & 11.0 & 7.8 & 8.9 & 9.5 & 9.5 & 9.3 \\
\hline FR & 51.3 & 48.1 & 46.3 & 40.7 & 41.2 & 42.6 & 40.4 & 32.1 & 30.0 & 34.2 & 32.6 & 32.0 \\
\hline $\mathrm{HR}$ & 2.2 & 2.5 & 2.5 & 2.8 & 3.3 & 3.6 & 3.3 & 2.6 & 2.6 & 2.4 & 2.3 & 2.1 \\
\hline IT & 20.7 & 20.3 & 22.2 & 22.8 & 24.2 & 25.3 & 23.8 & 17.8 & 18.6 & 19.8 & 20.2 & 19.0 \\
\hline LV & 15.0 & 18.0 & 18.6 & 19.8 & 16.8 & 18.3 & 19.6 & 18.7 & 17.2 & 21.4 & 21.9 & 19.5 \\
\hline LT & 9.8 & 11.5 & 11.6 & 12.5 & 12.9 & 14.4 & 14.7 & 11.9 & 13.4 & 15.1 & 14.2 & 13.3 \\
\hline LU & 0.6 & 0.5 & 0.6 & 0.4 & 0.4 & 0.6 & 0.3 & 0.2 & 0.3 & 0.3 & 0.2 & 0.2 \\
\hline HU & 7.8 & 7.6 & 8.7 & 9.1 & 10.2 & 10.0 & 9.9 & 7.7 & 8.8 & 9.1 & 9.2 & 9.7 \\
\hline
\end{tabular}




\begin{tabular}{|c|c|c|c|c|c|c|c|c|c|c|c|c|}
\hline 1 & 2 & 3 & 4 & 5 & 6 & 7 & 8 & 9 & 10 & 11 & 12 & 13 \\
\hline NL & 4.0 & 4.7 & 5.8 & 5.9 & 6.3 & 7.2 & 7.0 & 5.6 & 5.9 & 6.4 & 6.2 & 6.1 \\
\hline AT & 17.1 & 16.9 & 18.8 & 19.0 & 21.0 & 21.4 & 21.9 & 17.8 & 19.8 & 20.3 & 19.5 & 19.3 \\
\hline PL & 46.6 & 47.4 & 52.3 & 50.0 & 53.6 & 54.3 & 52.0 & 43.4 & 48.7 & 53.7 & 48.9 & 50.9 \\
\hline PT & 2.2 & 2.1 & 2.3 & 2.4 & 2.4 & 2.6 & 2.5 & 2.2 & 2.3 & 2.3 & 2.4 & 2.3 \\
\hline RO & 15.2 & 15.0 & 17.0 & 16.6 & 15.8 & 15.8 & 15.2 & 11.1 & 12.4 & 14.7 & 13.5 & 12.9 \\
\hline SI & 3.1 & 3.0 & 3.1 & 3.2 & 3.4 & 3.6 & 3.5 & 2.8 & 3.4 & 3.8 & 3.5 & 3.8 \\
\hline SK & 10.4 & 10.1 & 9.7 & 9.5 & 10.0 & 9.6 & 9.3 & 7.0 & 8.1 & 8.0 & 7.6 & 8.5 \\
\hline $\mathrm{FI}$ & 9.7 & 10.0 & 10.1 & 9.7 & 11.1 & 10.4 & 10.8 & 8.9 & 9.8 & 9.4 & 9.3 & 9.5 \\
\hline SE & 19.2 & 20.2 & 20.9 & 21.7 & 22.3 & 23.3 & 22.9 & 20.4 & 23.5 & 22.9 & 22.0 & 21.0 \\
\hline UK & 18.5 & 18.7 & 22.6 & 21.4 & 21.9 & 21.3 & 21.1 & 19.2 & 18.6 & 21.0 & 21.4 & 22.4 \\
\hline
\end{tabular}

Source: www.ec.europa.eu/transport/facts-fundings/statistic/pocketbook-2015_en.

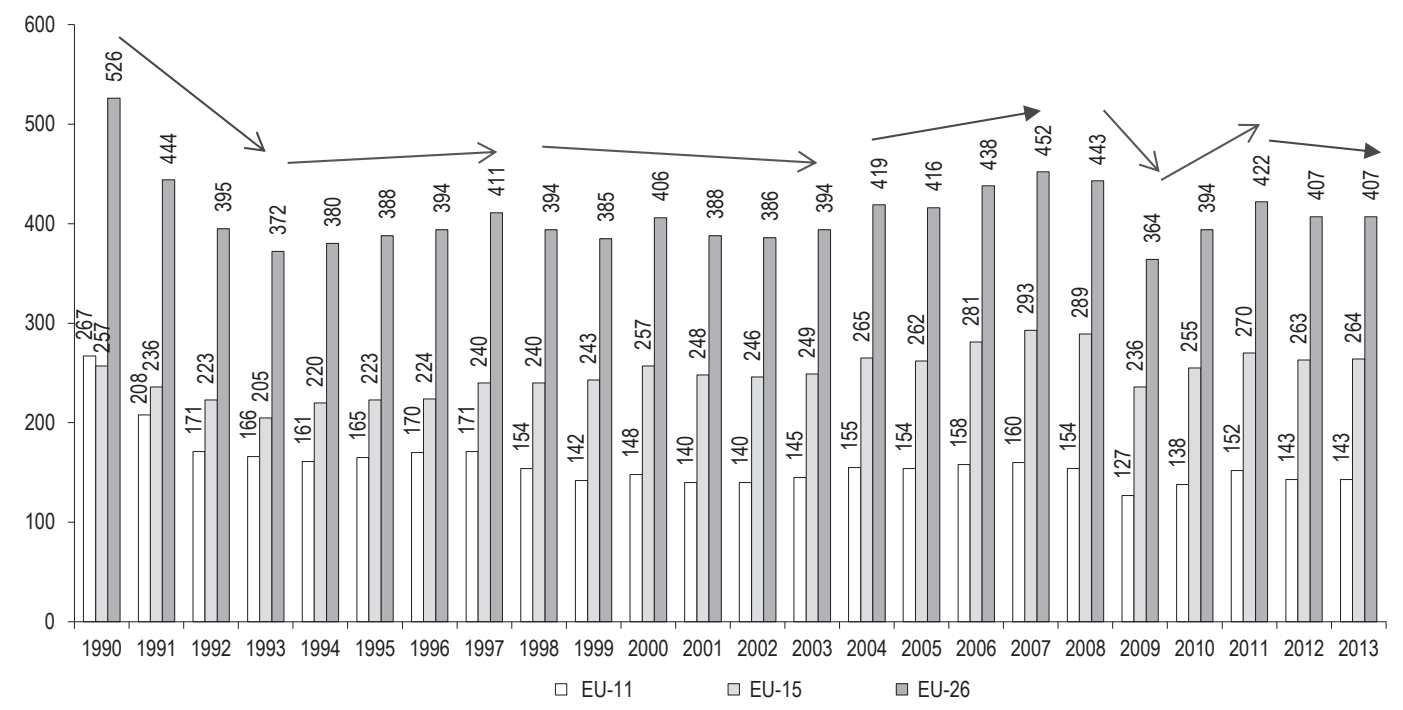

Figure 1. Rail freight transport in the European Union in the years 1990-2013 by group of countries (billion tkm)

Source: www.ec.europa.eu/transport/facts-fundings/statistic/pocketbook-2015_en.

25.3 billion tkm in 2007, and once again observed a decrease at the level of 19.0 billion tkm in 2013. In the context of fluctuations observed on the Italian market, it is worth noting a spectacular decline in rail freight transport in the years 1995-2013 in France. In 1995, France, with transport at the level of 48.3 billion tkm, constituted the second largest railway freight market after Germany. By 2013, the French market fell to the level of 32.0 billion tkm (33.7\%). As a result of this decrease, France moved to the third place in terms of the size of the rail freight market in the European Union. Poland took the second place with transport at the level of 50.9 billion tkm. 
Figure 1 presents aggregated data concerning the rail freight market in the European Union in the years 1990-2013. Additionally, a group of the so-called "old 15 "5 countries was compared separately with the group of the "new" EU-11 countries that joined the EU in 2004-2007, together with Croatia, ${ }^{6}$ which became part of the EU in 2013, but, without Cyprus and Malta, as they do not have a railway network.

With regard to the entire EU rail freight market in the years 1990-2013, various development phases can be observed on the basis of the data presented in the figure. In the years 1990-1994, the market decreased from the level of 526.3 billion tkm in 1990 to 380.2 billion tkm in 1994, i.e. by $27.8 \%$, and then from 1995 it faced a quite slow, several-year long upward trend until 2007. During this period, the entire market grew from 388.1 billion tkm in 1995 to 452 billion tkm in 2007 (16.5\%). In 2008-2013, apart from the fluctuation in 2011, the declining trend of the entire market was maintained again, as it fell from the level of 442.8 billion tkm in 2008 to 406.5 billion tkm in 2013 , i.e. by $8.2 \%$. When analysing the data presented in the figure concerning the groups of the EU-15 and EU-11 countries, there could be observed phenomena that both groups followed the general trend, as well differed from it. Undoubtedly, the downward trend of markets in the years 1990-1994 was consistent with the general trend of decrease in rail freight transport, with the fact that the market decline in the EU-11 group was greater (40.5\%) if compared to the EU-15 (14.4\%).

Starting from 1995, the markets of the entire EU-15 countries experienced a growing trend, which continued until 2007. During this period, the rail freight market increased in this group of countries from 222.7 billion tkm to 292.5 billion tkm, (31.3\%). In the same period, the rail freight market in the EU-11 group decreased from 165.4 billion tkm to 159.5 billion tkm, (3.6\%). In the years 2008-2013, both analysed groups of countries experienced declines in the rail freight transport market. In the EU-15 group, the 2013/2008 decline in the market amounted to $8.8 \%$, while in the EU-11 group this decrease was equal to $7.2 \%$ for the corresponding period. Continuing the analysis of data from Figure 1 , it is worth noting that the entire rail freight market in the European Union experienced decrease from the 526 billion tkm in 1990 to 407 billion tkm in 2013, or 22.6\% in relative terms. In the same period, the freight transport market in the EU-15 group, starting from 257 billion tkm in 1990, and then subject to various fluctuations, reached the level of 264 billion tkm in 2013, thus it increased by $2.7 \%$, in comparison with the starting year. However, the rail freight market in the EU-11 countries suffered a decrease from 267 billion tkm in 1990 to 143 billion tkm in 2013 (46.4\%). As a result of this process, the relative share of EU-11 countries in the EU rail freight market decreased from $50.8 \%$ in 1990 to $35.1 \%$ in 2013 .

\section{Conclusions}

The preliminary conclusion resulting from the analysis of transport statistics covering the commodity market, in the context of the railway liberalization policy implemented in the European Union, is that the argument stating that liberalization should lead to an increase in the relative share of rail transport in the transport market is not fully confirmed. The statistics clearly show that in the 1990s, when the liberalization policy of the railway sector was

5 The group consists of Austria - AT, Belgium - BE, Germany - DE, Denmark - DK, Greece - EL, Spain - ES, Finland - FI, France - FR, Ireland - IE, Italy - IT, Luxembourg - LU, Netherlands - NL, Portugal - PT, Sweden - SE, United Kingdom - UK.

${ }^{6}$ The group consists of Bulgaria - BG, Czech Republic - CZ, Estonia - EE, Croatia - HR, Lithuania - LT, Latvia - LV, Poland - PL, Romania - RO, Slovenia - SI, Slovakia - SK. 
initiated, and later in the 2000 s, the freight market had been systematically growing with the main beneficiary being road transport. On the other hand, the rail transport in total either decreased or increased at a low pace from 1990 to 2013 , which led to a decline in its relative share in the market.

However, when taking into account two important aspects, it seems that the preliminary conclusion does not contradict the general idea of the railway sector liberalization policy. Firstly, currently, when more than a quarter of century has passed since the implementation of the policy of liberalization and demonopolization of the rail sector in the European Union, the development of the transport market could not be verified, if the reforms liberalizing the railway sector were not undertaken, thus maintaining sector monopoly in all countries, as it was the case in the early 1990s. However, it is hard to imagine that railway monopolies, which were legally established in accordance with railway legislation, would participate in effective competitive struggle, especially with road transport companies, and would thus increase in the next quarter-century the share of rail in the transport market to a level significantly higher than the level of $11.7 \%$ achieved in 2013 . Secondly, the railway sector liberalization policy has led, and continues to do so, to an increase in the competitiveness of railways in relation to other modes of transport, for example, by directly influencing the adaptation of transport capacity of railway undertakings to competitively take over cargoes from other modes of transport, pressuring to reduce costs while improving the quality of transport and customer services. However, this policy itself does not generate other important demand factors for rail freight transport.

The level of demand for rail transport depends on various factors affecting the demand side of the rail freight market. The most important factors include (Engelhardt, 2014, pp. 79-81): the status of economic development and the level and rate of GDP changes; the level of investment in the economy, especially infrastructure investments; the structure of exports and imports in the interchangeable relations of individual countries; flexibility of both price and income of the demand for rail freight transport; "craving" of potential customers for comprehensive, logistic transport services; the degree of development of cargo containerization and intermodal transport systems; potential of transport modes substitutable to the rail; as well as competitive transport prices offered by these modes. Demand for rail freight from the supply side of the market also depends on many factors, such as (Engelhardt, 2014, pp. 79-81) spatial availability of stations and loading points; quantity and quality of equipment (processing capacity) of border, port and the so-called rail - port terminals; competitiveness in terms of location of transit rail transport through a given country; existence of capacity and transport reserves in specific transport relations (desired by potential customers); general quality of railway infrastructure, determining the speed of cargo shipments, punctuality and timeliness of transport; as well as price competitiveness of railway undertakings determined mainly by labour costs and external prices: repair services, fuels and electricity, as well as the level of access rates to the railway infrastructure.

As presented above, there are many factors that determine the overall demand for rail freight transport. Most of them are exogenous in nature with respect to railway undertakings, thus causing fairly loose relationships between the policy of liberalization of the sector and the volume of demand for rail transport. 


\section{References}

Council Directive of 29 July 1991 on the Development of the Community's Railways (91/440/EEC) - the Official Journal of the European Communities 1991, L 237/25.

Directive 2012/34/EU of the European Parliament and of the Council of 21 November 2012 establishing a single European railway area - the Official Journal of the European Communities 2012, L 343/32.

Engelhardt J. (2014). Zasady analizy i oceny działalności gospodarczej przedsiębiorstw kolejowych. Warszawa: CeDeWu.

Statistical pocketbook 2015. Retrieved from: www.ec.europa.eu/transport/facts-fundings/statistic/pocketbook-2015_en.

Cite this article aS: Engelhardt, J. (2018). Direction of changes in demand for rail freight transport within the European Union countries in the years 1990-2013. European Journal of Service Management, 3 (27/1), 89-97. DOI: 10.18276/ejsm.2018.27/1-11. 